\title{
PENGEMBANGAN APLIKASI ONLINE PUBLIC ACCESS CATALOG (OPAC) PERPUSTAKAAN BERBASIS WEB PADA STAI AULIAURRASYIDDIN TEMBILAHAN
}

\author{
Dini Azzahra') , Siti Ramadhani, S.Pd, M.Kom²) \\ ${ }^{1)}$ Fakultas Sains dan Teknologi, Universitas Islam Negeri Sultan Syarif Kasim Riau, Jalan HR. Soebrantas \\ Pekanbaru \\ email: 11751201890@students.uin-suska.ac.id \\ ${ }^{2)}$ Fakultas Sains dan Teknologi, Universitas Islam Negeri Sultan Syarif Kasim Riau, Jalan HR. Soebrantas \\ Pekanbaru \\ email: siti.ramadhani@uin-suska.ac.id
}

\begin{abstract}
The Auliaurrasyidin STAI library has approximately 8000 books consisting of various types of discussion topics. The book is neatly arranged in a bookshelf so that visitors can find the desired book easily. The bookshelves are equipped with an alphabet that represents the beginning of the title of the book because the library only has a local-based book information gathering system or OPAC (Online Public Access Catalog) so it is very difficult to find books when we are not on a computer search table. Therefore, it was developed an Online Application Public Access Catalog Website based library using PHP programming language and designed using a MySQL database in order to facilitate the problem. This application was developed using the RAD (Rapid Application Deployment) method approach. The OPAC application that was developed has been through Black Box testing and UAT testing by obtaining the agreed range of results.
\end{abstract}

Keywords: Application, Book, OPAC, Library

\begin{abstract}
Abstrak
Perpustakaan STAI Auliaurrasyidin memiliki kurang lebih 8000 buku yang terdiri dari berbagai jenis topik pembahasan. Buku tersebut disusun rapi didalam rak buku agar pengunjug menemukan buku yang diinginkan dengan mudah. Rak buku tersebut dilengkapi dengan abjad yang mewakili awal judul buku karena perpustakaan tersebut hanya memiliki sistem temu informasi buku atau OPAC (Online Public Access Catalog) yang berbasis local sehingga sangat menyulitkan jika mencari buku pada saat kita tidak berada dimeja komputer pencarian. Oleh sebab itu maka dikembangkanlah Aplikasi Online Public Access Catalog Perpustakaan berbasis Website menggunakan Bahasa pemrograman PHP dan dirancang menggunakan database MySQL guna untuk memudahkan dalam permasalahan tersebut. Aplikasi ini dikembangkan dengan menggunkana pendekatan metode RAD (Rapid Application Deployment) Serta Aplikasi OPAC yang dikembangkan telah melalui pengujian Black Box dan pengujian UAT dengan memperoleh hasil rentang kategori setuju.
\end{abstract}

Keywords: Aplikasi, Buku,OPAC, Perpustakaan

\section{PENDAHULUAN}

Dewasa ini, sebuah perpustakaan dituntut untuk memberikan pelayanan yang memuaskan dengan memberikan pelayanan yang cepat, tepat dan tanggap. Katalog yang memanfaatkan teknologi dan jaringan internet menjadi sebuah pilihan 
untuk menjadikan sebuah perpustakaan lebih memberikan pelayanan yang lebih baik. Katalog yang berbasis website tersebut dinilai lebih efisien waktu dalam pencarian buku yang dilakukan oleh pengunjung. Selain itu, katalog online yang disediakan juga sangat bermanfaat karena dapat mencari dimana saja dan kapan saja terhadap sesuatu yang dicari dan diinginkan.

Katalog berbasis website diperlukan dalam pelayanan sebuah perpustakaan. Katalog ini disebut juga dengan opac. Online Public Access Catalog (OPAC) merupakan sarana penelusuran yang diperuntukkan bagi yang membutuhkan informasi dari perpustakaan (Nugroho et al., 2018). Keberadaan OPAC selain sebagai katalog online, juga disebut sebagai bagian dari teknologi informasi yang menyuguhkan akses sistem temu balik informasi (Hutagaglung, 2018). pada STAI Auliaurrsyidin Tembilahan, keberadaan opac ini dapat membantu anggota perpustakaan khususnya mahasiswa yang ingin menemukan sebuah buku dimanapun didalam perpustakaan tanpa harus mencari hanya pada salah satu mesin pencari atau OPAC local (Ramadhani et al., 2018). Karena katalog buku berbasis website telah menampilkan daftar buku secara detail serta dilengkapi fitur pencarian yang dapat memudahkan pengunjung dalam pencarian buku yang dapat dilakukan dimana saja (Siti, 2015). Sehingga pengunjung perpustakaan dapat mencari buku yang diinginkan sesuai dengan informasi rak yang telah didapat.

Berdasarkan permasalahan dengan melihat kesulitan yang dihadapi oleh pengunjung melalui Inkubator Bisnis Teknik Informatika, Sekolah Tinggi Agama Islam Auliaurrsyiddin kesulitan dalam mencari buku di perpustakaan kampus (Nazwita, Siti, 2017). Oleh karena itu, penulis mengangkat judul "Pengembangan Aplikasi Online Public Access Catalog Perpustakaan berbasis
Web pada STAI Auliaurrasyiddin Tembilahan" guna untuk memberikan keefisienan waktu pada saat mencari sebuah buku, jurnal atau karya ilmiah lainnya.

\section{METODE PENELITIAN}

\section{Metode Pendekatan Analisis Sistem}

Metode analisis sistem pada pengembangan aplikasi ini menggunakan pendekatan UML. Unified Modelling Language (UML) adalah sebuah "bahasa" yang telah menjadi standar dalam industri untuk visualisasi, merancang, dan mendokumentasikan sisem piranti lunak. UML menawarkan sebuah standar untuk merancang model sebuah sistem(Arismanto \& Rahmadhani, 2019).

\section{Usecase Diagram}

Use Case Diagram adalah model UML yang digunakan untuk menunjukkan grafik kasus penggunaan dan hubungannya dengan pengguna. UML atau Unified Modeling Language adalah set standar diagram dan konstruksi model yang digunakan dalam pengembangan system.

2. Sequence Diagram

Sequence Diagram adalah model dinamis yang mendukung pandangan dari sistem yang berkembang. Sequence Diagram menekankan urutan waktu berdasarkan aktivitas itu berlangsung di antara sekumpulan objek, mereka sangat membantu untuk memahami real-time spesifikasi yang rumit (Dennis et al., 2015).

3. Class Diagram

Class Diagram adalah model statis yang mendukung tampilan statis sistem yang berkembang. Ini menunjukkan kelas dan hubungan antar kelas yang tetap konstan dalam sistem seiring waktu. Diagram kelas sangat mirip dengan diagram 
hubungan entitas (ERD) (Dennis et al., 2015).

\section{Metode Rancangan Penelitian}

Metode penelitian yang diterapkan pada penelitian ini adalah dengan pengembangan metode Rapid Application Development (RAD). RAD adalah sebuah model proses perkembangan perangkat lunak sekuensial linier yang menekankan siklus perkembangan yang sangat pendek. Model RAD ini merupakan sebuah adaptasi "kecepatan tinggi" dari model sekuensial linier dimana perkembangan cepat dicapai dengan menggunakan pendekatan konstruksi berbasis komponen(Ridwan, Muhammad \& Ramadhani, 2017). Jika kebutuhan dipahami dengan baik, proses RAD memungkinkan tim pengembangan menciptakan "sistem fungsional yang utuh" dalam periode waktu yang sangat pendek (kira-kira dalam waktu 60-90 hari) (Hidayati, 2018).

\section{Ruang Lingkup Aplikasi}

Adapun terdapat beberapa ruang lingkup aplikasi pada penilitian ini, yaitu:

a. Penelitian ini dilakukan hanya pada bagian di Perpustakaan STAI Auliaurrasyiddin yaitu bagian meja pencarian buku.

b. Sistem ini hanya melakukan pencarian buku yang dilakukan oleh pengunjung perpustakaan STAI Auliaurrasyiddin.

c. Sistem ini hanya dapat mengelola buku yang terdapat didalam perpustakaan STAI Auliaurrasyiddin.

d. Sistem ini dapat melihat data buku yang dihapus dan ditambahkan setiap bulan sebagai laporan kepada pimpinan.

\section{Kerangka Pembangun Aplikasi}

Aplikasi berbasis website ini dikembangkan menggunakan Bahasa php dengan framework Laravel. Framework Laravel merupakan sebuah Framework PHP (PHP Hypertext Preprocessor) yang dirilis dibawah lisensi MIT, dibangun dengan konsep MVC (Model, View, Controller). Laravel adalah sebuah MVC web development framework yang didesain untuk meningkatkan kualitas perangkat lunak dengan mengurangi biaya pengembangan dan perbaikan serta meningkatkan produktifitas pekerjaan dengan sintak yang bersih dan fungsional yang dapat mengurangi banyak waktu untuk implementasi (Luthfi, 2017). Sedangkan untuk membangun client side nya, aplikasi ini menggunakan vue js. Framework Vue.js (dibaca: vyuu atau viuu) merupakan sebuah Framework JavaScript progresif yang digunakan untuk membangun tampilan User interface dengan mengacu pada arsitektur MVC (Model, View, Controller) (Aditya et al., 2019).

\section{Tempat Penelitian}

Aplikasi ini dikembangkan di Inkubator Bisnis Teknik Informatika Universitas Islam Negeri Sultan Syarif Kasim Riau. Di Inkubator Bisnis ini, permasalahan pada STAI Auliaurrasyiddin Tembilahan di Analisa.

\section{Teknik Pengumpulan Data}

Teknik pengumpulan data pada pengembangan aplikasi opac berbasis web ini terbagi atas 3, yaitu observasi, wawancara dan studi Pustaka. Didalam Tahapan obeservasi, penulis melakukan penelitian dan pengamatan melalui Inkubator Bisnis Teknik Informatika. Didalam Tahapan ini penulis melakukan wawancara dengan Bapak Pizaini, ST, M. Kom yang merupakan pembimbing instansi yang ada di Inkubator Bisnis Teknik Informatika. Dan di tahapan studi Pustaka, penulis melakukan pengumpulan pada data. Dimana pada tahap ini 
dilakukan pencarian pada sumber-sumber buku, internet atau jurnal - jurnal mengenai informasi yang berkaitan dengan Pengembangan Aplikasi Online Public Access Catalog Berbasis Web.

\section{HASIL DAN PEMBAHASAN}

Analisa sistem adalah proses penguraian sebuah sistem informasi atau aplikasi yang masih utuh ke berbagai komponen dasarnya dengan tujuan agar bisa dikenali dan dinilai berbagai macam permasalahan dan hambatan yang timbul pada sistem sehingga nantinya bisa dilakukan penyelesaian, koreksi, dan peningkatan. Orang atau kelompok orang yang melakukan koreksi atau pengembangan sistem disebut dengan sistem analis. Analisa sistem lama memiliki proses sebagai berikut :

Proses bisnis sistem yang lama dimulai dari pencarian buku yang dilakukan oleh pengunjung perpustakaan. Sebelum mencari buku yang diinginkan di rak buku yang tersusun, pengunjung perpustakaan akan mencari buku disebuah komputer yang memiliki sistem OPAC. Setelah mendapatkan informasi rak mengenai buku yang diinginkan, pengunjung menelusuri dan mencari buku sesuai nomor rak yang tersedia. Selanjutnya, jika pengunjung tersebut mencari buku lain yang dibutuhkan, maka harus mengujungi komputer yang sama dimeja penjaga perpustakaan. Selain itu, untuk mendata buku yang ada diperpustakaan, pihak pustakawan mencatat dan merekap data buku hanya pada salah satu kompter saja atau hanya pada salah satu mesin pencari saja.

Sementara Analisa sistem baru memiliki proses sebagai beriku :

Dalam analisis sistem baru ini, sistem atau aplikasi yang dikembangkan berbasis website. Sistem OPAC ini bisa diakses dimana saja hanya dengan mengunjungi website milik perpustakaan STAI Auliaurrasyidin tersebut. Pengunjung dapat mencari informasi mengenai buku yang diinginkan dengan mengunjungi website, yang dapat diakses didalam perangkat perpustakaan atau perangkat yang ada diluar perpustakaan.

\section{Analisa Fungsionalitas}

Berikut ini adalah gambaran rancangan use case diagram yang terdapat didalam sistem.

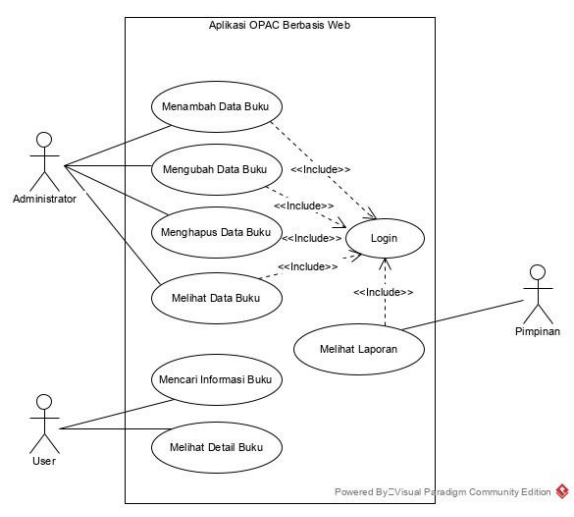

Gambar 1 Use Case Diagram

Sequence Diagram digunakan untuk memperlihatkan aliran eksekusi dari setiap aliran yang ada pada use case. Gambar berikut ini merupakan penggambaran aliran eksekusi dari setiap aliran yang ada pada use case Pengembangan Aplikasi Online Public Access Catalog Perpustakaan berbasis Web pada STAI Auliaurrasyidin. Berikut adalah gambaran sequence diagram aplikasi opac:

Seqeunce diagram untuk login sebagai administrator dan pimpinan. 


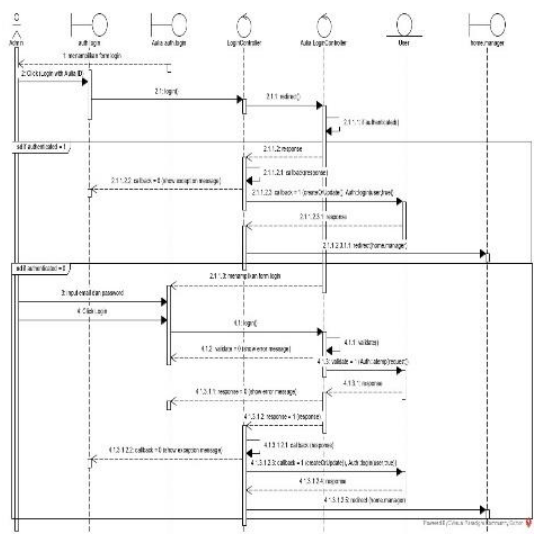

Gambar 2 Sequence Diagram Login

Sequence diagram menambah data buku sebagai administrator

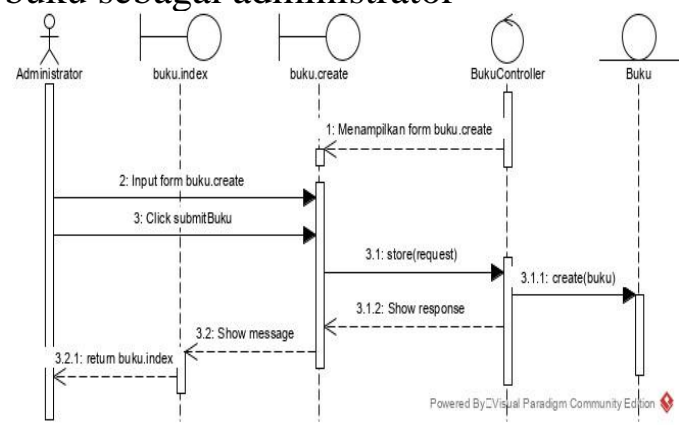

Gambar 3 Sequence Diagram Menambah Data Buku

Sequence diagram mengubah data buku sebagai administrator

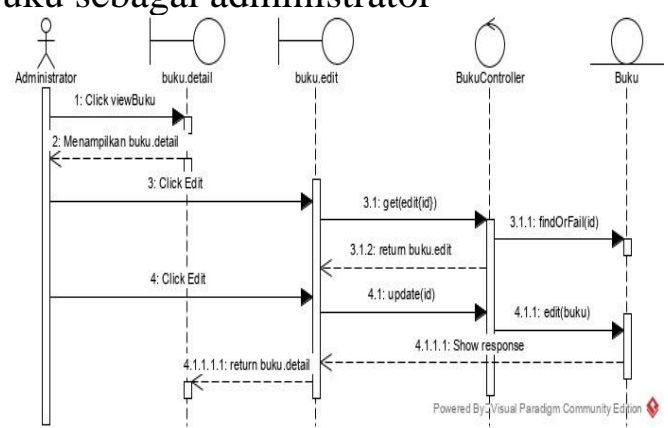

Gambar 4 Sequence Diagram Mengubah Data Buku

Sequence diagram menghapus data buku sebagai administrator

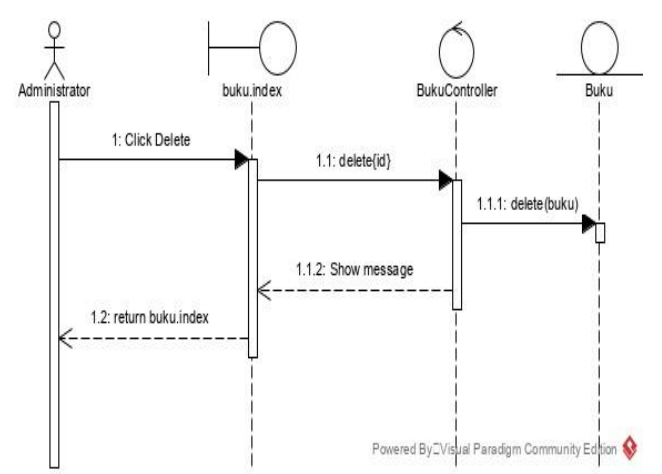

Gambar 5 Sequence Diagram Menghapus Data Buku

Sequence diagram melihat data buku sebagai administrator

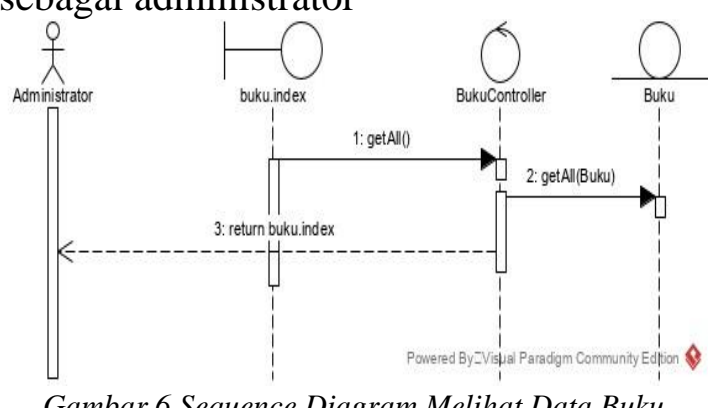

Gambar 6 Sequence Diagram Melihat Data Buku

Sequence diagram mencari informasi buku sebagai pengujung dan administrator

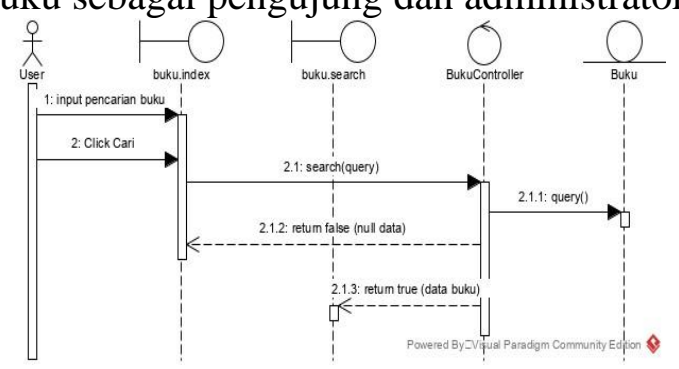

Gambar 7 Sequence Diagram Mencari Informasi Buku

Sequence diagram melihat detail buku sebagai pengujung dan administrator

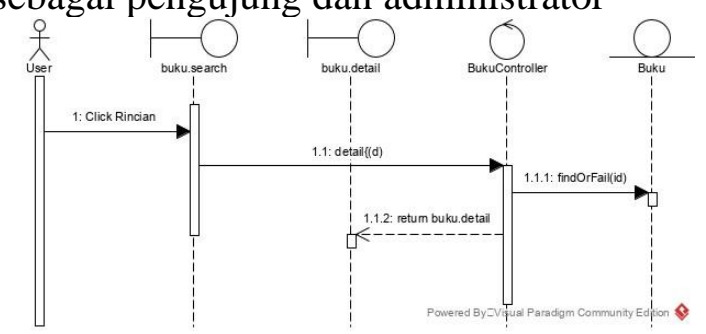

Gambar 8 Seqeunce Diagram Melihat Detail Buku

Sequence diagram melihat laporan sebagai pimpinan 


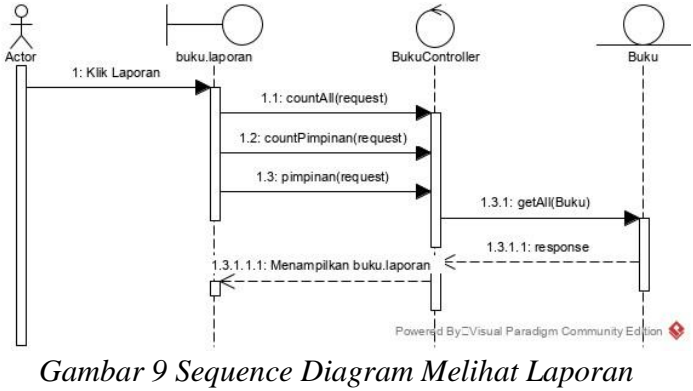

Class Diagram adalah model statis yang mendukung tampilan statis sistem yang berkembang. Ini menunjukkan kelas dan hubungan antar kelas yang tetap konstan dalam sistem seiring waktu. Class Diagram menggambarkan struktur sistem dari segi pendefinisian kelas-kelas apa yang akan dibuat untuk membangun system. Gambar berikut merupakan penggambaran Pengembangan Aplikasi Online Public Access Catalog Perpustakaan berbasis Web dari segi pendefinisian kelas apa yang akan dibuat untuk membangun sistem.

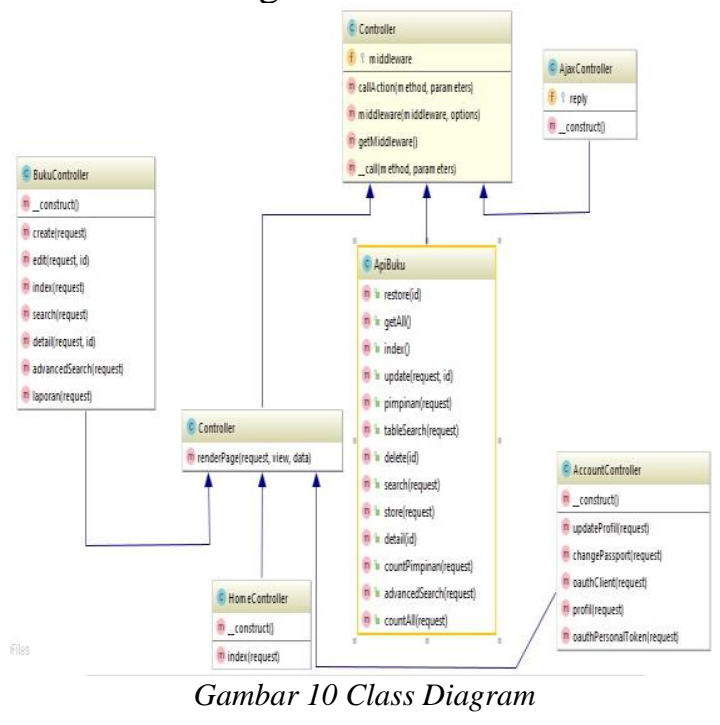

2. Implementasi Sistem

Implementasi sistem yang dilakukan sesuai dengan analisa dan perancangan sistem yang telah dibuat sebelumnya. Berikut adalah hasil implementasi dari Pengembangan Aplikasi Online Public Access Catalog Perpustakaan pada STAI Auliaurrasyidin.

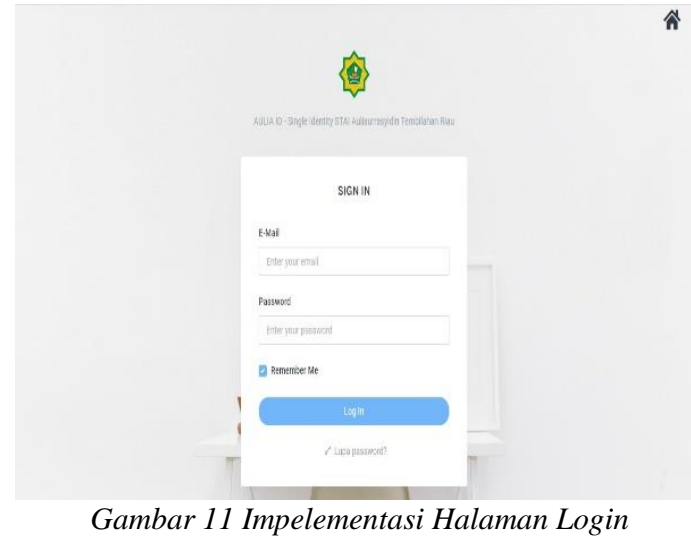

Gambar 11 Impelementasi Halaman Login

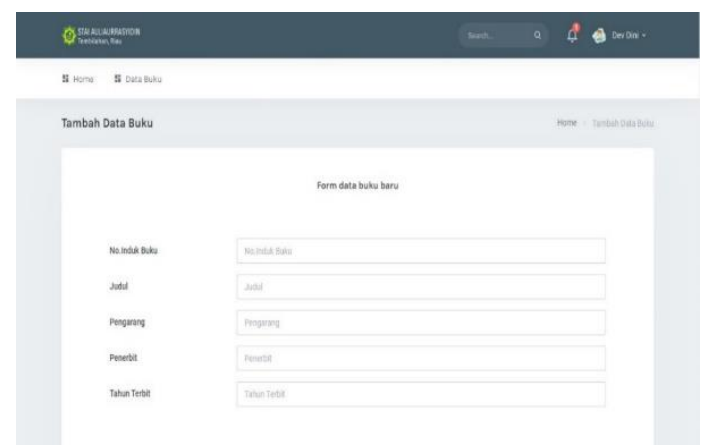

Gambar 12 Impelementasi Halaman Tambah Data Buku

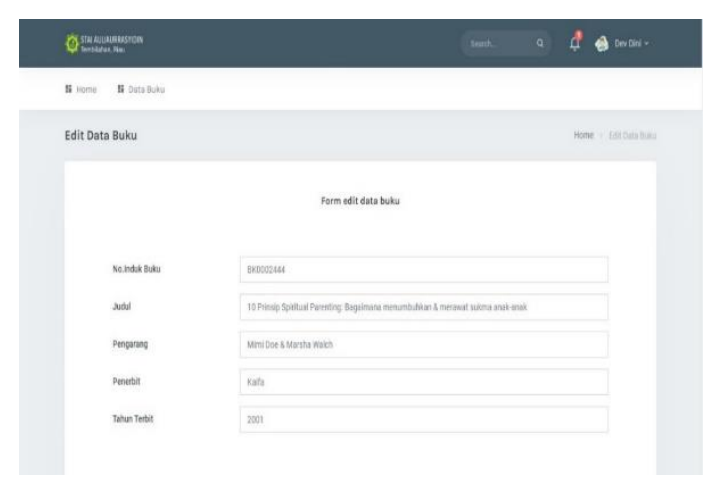

Gambar 13 Implementasi Halaman Ubah Data Buku

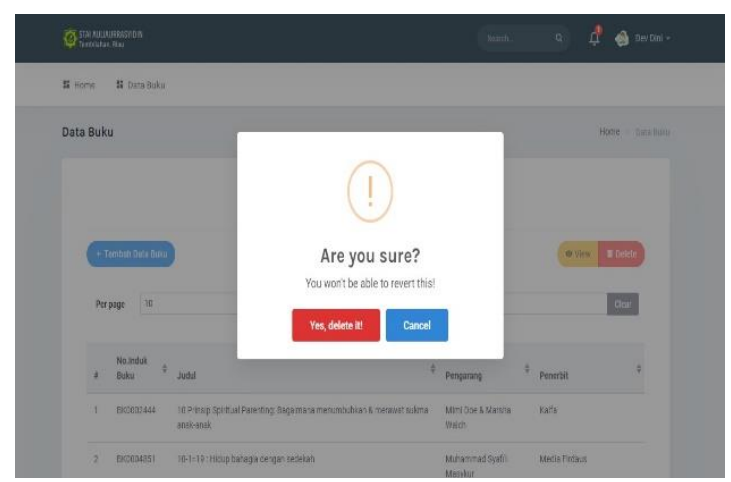

Gambar 14 Impelementasi Halaman Hapus Data Buku 

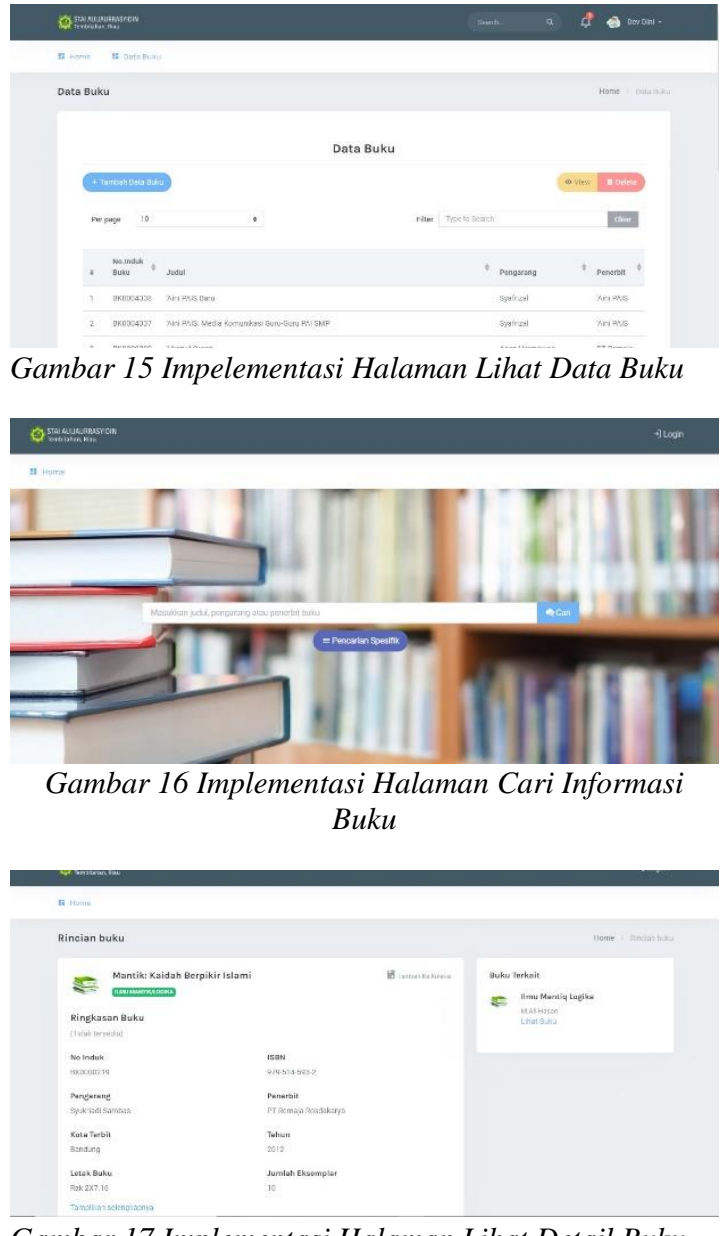

Gambar 17 Implementasi Halaman Lihat Detail Buku

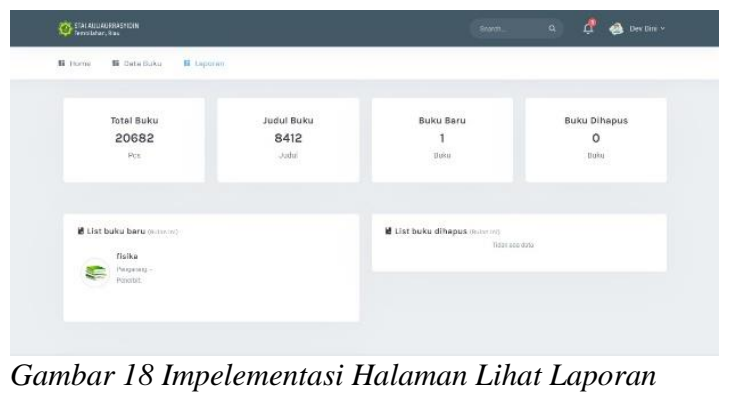

3. Pengujian dan Hasil Uji

Pengujian pada sistem dilakukan setelah tahap implementasi selesai. Pengujian dilakukan dengan tujuan melihat apakah sistem yang dibuat sudah sesuai dengan tujuan yang ditetapkan dan apakah sistem sudah layak untuk digunakan. Pada Pengembangan Aplikasi Online Public Access Catalog Perpustakaan ini, pengujian dilakukan dengan metode black box dan UAT (User Acceptance Test).
Metode pengujian black box adalah suatu teknik pengujian yang dilakukan tanpa perlu mengetahui struktur internal dari software yang akan diuji karena pengujian ini hanya berfokus kepada input dan output terhadap spesifikasi suatu software. Pada penelitian ini, pengujian black box dinyatakan sukses karena semua test case yang diuji menunjukkan dan memberikan nilai sukses.

Metode pengujian UAT (User Acceptance Test) merupakan suatu metode pengujian oleh pengguna untuk menghasilkan sebuah dokumen yang bertujuan sebagai bukti bahwa sistem yang dibuat telah dapat diterima oleh pengguna. Pengujian UAT pada sistem ini dilakukan dengan menggunakan skala Likert yaitu memberikan kuisoner atau mengajukan beberapa pertanyaan kepada pengunjung, pegawai dan pimpinan (Wardhono et al., 2015). Pada pengujian UAT ini terdapat 5 kategori yaitu SS (Sangat Setuju), S (Setuju), CS (Cukup Setuju), KS (Kurang Setuju), TS (Tidak Setuju). Berikut ini rincian hasil pengujian UAT pada mahasiswa didaerah Riau.

Perhitungan pada total jawaban responden pada tabel diatas adalah sebagai berikut:

a. $\quad$ Sangat Setuju $(S S)=5 \times 33=165$

b. $\operatorname{Setuju}(\mathrm{S}) \quad=4 \times 50=200$

c. Cukup Setuju (CS) $=3 \times 5=15$

d. Kurang Setuju $(\mathrm{KS})=2 \times 2=4$

e. Tidak Setuju (TS) $=1 \times 0=0$

$$
\text { Total Skor } \quad=384
$$

Berikut adalah total nilai yang dikumpulkan dari responden : 


\begin{tabular}{|c|c|c|c|c|c|c|}
\hline No & Pertanyaan & SS & $\mathrm{S}$ & CS & KS & TS \\
\hline 1. & $\begin{array}{l}\text { Sistem OPAC mudah digunakan oleh } \\
\text { pengguna baru }\end{array}$ & 5 & 4 & 0 & 0 & 0 \\
\hline 2. & $\begin{array}{l}\text { Sistem OPAC ringan untuk diakses } \\
\text { diplatform apa saja }\end{array}$ & 2 & 6 & 1 & 0 & 0 \\
\hline 3. & $\begin{array}{l}\text { Sistem OPAC berjalan sesuai } \\
\text { diinginkan }\end{array}$ & 2 & 6 & 1 & 0 & 0 \\
\hline 4. & $\begin{array}{l}\text { Sistem OPAC memudahkan } \\
\text { pengunjung dalam mencari informasi } \\
\text { buku }\end{array}$ & 5 & 4 & 0 & 0 & 0 \\
\hline 5. & Tampilan sistem OPAC menarik & 3 & & 1 & & 0 \\
\hline 6. & $\begin{array}{l}\text { k icon dan menu disusun } \\
\text { api }\end{array}$ & 5 & 3 & 0 & 1 & 0 \\
\hline 7. & $\begin{array}{l}\text { Setiap tombol berjalan sesuai } \\
\text { fungsinya }\end{array}$ & 4 & 4 & 1 & 0 & 0 \\
\hline 8. & Informasi buku yang diberika & 5 & 2 & 1 & 1 & 0 \\
\hline 9. & $\begin{array}{l}\text { Sistem ini sudah layak digunakan } \\
\text { dalam keseharian }\end{array}$ & 2 & 7 & 0 & 0 & 0 \\
\hline 10. & $\begin{array}{l}\text { Anda puas dengan sistem opac dalam } \\
\text { penggunaannya }\end{array}$ & 0 & 9 & 0 & 0 & 0 \\
\hline
\end{tabular}

Kemudian dilakukan perhitungan nilai $\mathrm{X}$ (skor tertinggi) dan $\mathrm{Y}$ (skor terendah) sebagai berikut:

$\mathrm{X}=$ Skor tertinggi $\mathrm{x}$ (jumlah pernyataan $\mathrm{x}$ jumlah responden) $=5 \times 50=250$

$\mathrm{Y}=$ Skor terendah $\mathrm{x}$ (jumlah pernyataan $\mathrm{x}$ jumlah responden) $=1 \times 50=50$

Setelah itu dilakukan perhitungan persentase UAT menggunakan persamaan rumus sebagai berikut:

$$
\begin{aligned}
\text { Persentase UAT } & =\frac{\text { Total } \text { Skor }}{x} \times 100 \% \\
& =\frac{200}{250} \times 100 \% \\
& =80 \%
\end{aligned}
$$

Maka didapatlah kesimpulan, bobot skor tertinggi diantara kategori lainya yaitu kategori setuju dengan nilai responden 50 dan total skor sebanyak 200. Hal ini menunjukkan bahwa Pengembangan Aplikasi Online Public Access Catalog Perpustakaan berbasis web dapat diterima oleh pengguna karena range penilaian persetujuan pengguna termasuk kategori Setuju karena berada pada range $61 \%$ $80 \%$.

\section{SIMPULAN}

Metode perancangan yang digunakan didalam mengembangkan aplikasi ini yaitu metode pengembangan RAD (Rapid Application Depelopment). RAD adalah sebuah model proses perkembangan perangkat lunak sekuensial linier yang menekankan siklus perkembangan yang sangat pendek. Metode analisis sistem pada pengembangan aplikasi ini menggunakan pendekatan UML. Pengembangan Aplikasi Online Public Access Catalog ini terdiri dari metode perancangan UML seperti usecase diagram, sequence diagram dan class diagram. Metode pengujian yang dilakukan dalam mengembangkan aplikasi Online Public Access Catalog ini yaitu metode pengujian Blacbox dan UAT dengan perhitungan menggunakan skala likert.

Serta berdasarkan hasil pengujian kepada pengguna, maka diperolehlah rentang atau range persetujuan pengguna dengan nilai rentang $61 \%-80 \%$ dan termasuk kategori setuju.

\section{UCAPAN TERIMAKASIH}

Rasa syukur dengan mengucap Alhamdulillah penulis panjatkan atas kehadiran Allah SWT, Yang telah memberikan segala kenikmatan besar, baik nikmat iman, kesehatan dan kekuatan didalam melakukan penelitian dan Menyusun jurnal ini. Salawat beriringkan salam dilanturkan kepada Sayyidina Muhammad SAW. Allahumma shalli'ala sayyidina Muhammad wa'ala ali sayyidina Muhammad. Tidak lupa juga mengucapkan terima kasih kepada ibu Siti Ramadhani, S.Pd.,M.Kom. yang telah memberikan arahan dan semangat selama penulis menyusun dan melakukan penelitian ini.

\section{DAFTAR PUSTAKA}


Aditya, I. K., Putra, H., Pramana, D., Luh, N., \& Srinadi, P. (2019). Sistem Manajemen Arsip Menggunakan Framework Laravel dan Vue . Js ( Studi Kasus : BPKAD Provinsi Bali ). Sistem Dan Informatika, 13(2), 97-104.

Arismanto, B., \& Rahmadhani, S. (2019). Pengembangan Sistem Penerimaan Mahasiswa Baru pada STIES Imam Asy Syafii Pekanbaru. Jurnal IntraTech, 3(1), 57-72.

Dennis, A., Wixom, B. H., \& Tegarden, D. (2015). System Analysis and Design: An object-oriented approach with UML, 5th ed. In Journal of Chemical Information and Modeling (Vol. 53, Issue 9). https://doi.org/10.1017/CBO9781107 415324.004

Hidayati, N. (2018). Implementasi Metode Rapid Application Development Dalam Pembangunan Sistem Penerimaan Kas Atas Penjualan. Paradigma, XX(1), 3947.

Hutagaglung, P. D. (2018). Analisis Pemanfaatan Online Public Access Catalogue (OPAC) di Perpustakaan Universitas Medan Area. 82.

Luthfi, F. (2017). Penggunaan Framework Laravel Dalam Rancang Bangun Modul Back-End Artikel Website Bisnisbisnis.ID. JISKA (Jurnal Informatika Sunan Kalijaga), 2(1), 34. https://doi.org/10.14421/jiska.2017.2 1-05

Nazwita, Siti, R. (2017). Analisis Sistem
Keamanan Web Server Dan Database Server Menggunakan Suricata. Seminar Nasional Teknologi Informasi, Komunikasi Dan Industri (SNTIKI) 9, 308-317. Nugroho, F., Muljono, P., \& Hermadi, I. (2018). Pengembangan Online Public Access Catalog (Opac) Berbasis Android Pada Perpustakaan Upn "Veteran" Jakarta. Edulib, 7(2), 29-45.

https://doi.org/10.17509/edulib.v7i2. 9196

Ramadhani, S., Saide, S., \& Indrajit, R. E. (2018). Improving creativity of graphic design for deaf students using contextual teaching learning method (CTL). ACM International Conference Proceeding Series, 136140.

https://doi.org/10.1145/3206098.320 6128

Ridwan, Muhammad, M., \& Ramadhani, S. (2017). Rancangan Sistem Informasi Manajemen Aset di PT Sentral Tukang Indonesia. Jurnal CoreIT, 3(2), 47-53.

Siti, R. (2015). Sistem Pencegahan Plagiarisme Tugas Akhir Menggunakan Algoritma RabinKarp (Studi Kasus: Sekolah Tinggi Teknik Payakumbuh). Jurnal Teknologi Informasi \& Komunikasi Digital Zone, 6(1), 44-52.

Wardhono, W. S., Kusuma, L. P., \& Wardhono, W. S. (2015). Evaluasi User Acceptance Augmented Reality Triage Mobile Pada Sistem Kedaruratan Medis. Jurnal Sentar, 978-979. 